\title{
Contrasting trends of mass and optical properties of aerosols over the Northern Hemisphere from 1992 to 2011
}

\author{
K. C. Wang ${ }^{1}$, R. E. Dickinson ${ }^{2}$, L. Su ${ }^{3}$, and K. E. Trenberth ${ }^{4}$ \\ ${ }^{1}$ State Key Laboratory of Earth Surface Processes and Resource Ecology, College of Global Change and Earth System \\ Science, Beijing Normal University, Beijing, 100875, China \\ ${ }^{2}$ Department of Geological Sciences, The University of Texas at Austin, Austin, TX 78712, USA \\ ${ }^{3}$ Department of Information, Beijing City University, Beijing, 100083, China \\ ${ }^{4}$ National Center for Atmospheric Research, Boulder, CO 80307, USA
}

Correspondence to: K. C. Wang (kcwang@bnu.edu.cn)

Received: 18 June 2012 - Published in Atmos. Chem. Phys. Discuss.: 19 July 2012

Revised: 25 September 2012 - Accepted: 26 September 2012 - Published: 15 October 2012

\begin{abstract}
Atmospheric aerosols affect both human health and climate. PMX is the mass concentration of aerosol particles that have aerodynamic diameters less than $\mathrm{X} \mu \mathrm{m}, \mathrm{PM}_{10}$ was initially selected to measure the environmental impact of aerosols. Recently, it was realized that fine particles are more hazardous than larger ones and should be measured. Consequently, observational data for $\mathrm{PM}_{2.5}$ have been obtained but only for a much shorter period than that of $\mathrm{PM}_{10}$. Optical extinction of aerosols, the inverse of meteorological visibility, is sensitive to particles less than $1.0 \mu \mathrm{m}$. These fine particles only account for a small part of total mass of aerosols although they are very efficient in light extinction. Comparisons are made between $\mathrm{PM}_{10}$ and $\mathrm{PM}_{2.5}$ over the period when the latter is available and with visibility data for a longer period. $\mathrm{PM}_{10}$ has decreased by $44 \%$ in Europe from 1992 to 2009, $33 \%$ in the US from 1993 to 2010, $10 \%$ in Canada from 1994 to 2009, and 26\% in China from 2000 to 2011. However, in contrast, aerosol optical extinction has increased $7 \%$ in the US, $10 \%$ in Canada, and $18 \%$ in China during the above study periods. The reduction of optical extinction over Europe of $5 \%$ is also much less than the $44 \%$ reduction in $\mathrm{PM}_{10}$. Over its short period of record $\mathrm{PM}_{2.5}$ decreased less than $\mathrm{PM}_{10}$. Hence, $\mathrm{PM}_{10}$ is neither a good measure of changes in smaller particles nor of their long-term trends, a result that has important implications for both climate impact and human health effects. The increased fraction of anthropogenic aerosol emission, such as from vehicle exhaust, to total atmospheric aerosols partly explains this contrasting trend of optical and mass properties of aerosols.
\end{abstract}

\section{Introduction}

Atmospheric aerosols are a mixture of solid and aqueous species that enter the atmosphere by anthropogenic and natural pathways (Querol et al., 2004). They can be directly emitted from power plants, motor vehicles, industrial facilities, and natural sources, such as dust and ocean foam (Andreae et al., 2009). They can also be formed photo-chemically from reactions of primary gaseous species in the atmosphere, including $\mathrm{SO}_{2}$ and $\mathrm{NO}_{2}$ (Streets et al., 2007). Aerosols scatter and absorb solar radiation, reducing surface incident solar radiation and heating the aerosol layer (Ramanathan et al., 2007), hence changing atmospheric circulation and the water cycle (Rosenfeld et al., 2008; Kaufman et al., 2002).

$\mathrm{PM}_{10}$ has been widely selected by various Environmental Protection Agencies (EPAs) to measure environmental impact. However, the World Health Organization (WHO) recently announced that fine particles are more hazardous than larger ones in terms of mortality and cardiovascular and respiratory endpoints in panel studies (Englert, 2004). The loading of such fine particles could be estimated by measurement of $\mathrm{PM}_{2.5}$ or $\mathrm{PM}_{1.0}$ (Watson, 2002; Nicole Pauly, 2009). $\mathrm{PM}_{2.5}$ has been rountinely measured in some countries (see Sect. 2) while $\mathrm{PM}_{1.0}$ has not.

The impact of atmospheric aerosols on visibility through their scattering and absorption of solar radiation is especially sensitive to fine particles, i.e., those less than $1.0 \mu \mathrm{m}$ (Watson, 2002; Nicole Pauly, 2009), because these particles, comparable in size to the wavelength of visible solar radiation have 
the largest optical extinction efficiency. Meteorological visibility, which has been rountinely observed at weather stations and are globally availible from the early 20th centurty (Mahowald et al., 2007), provides a proxy of optical concentration of $\mathrm{PM}_{1.0}$. The inverse of optical extinction, meteorological visibility has been used successfully to quantify long-term variation of aerosols during the past four decades (Field et al., 2009; Vautard et al., 2009; Wang et al., 2009).

In summary, both health and climate are most strongly dependent on the fine particles with sizes of a few microns or less. Because the longest records and greatest numbers of observational sites are for the larger particles a key question is whether they could provide an adequate measure of the smaller particles, and hence health and climate effects. This question can be addressed using $\mathrm{PM}_{10}$ collected in Europe, the US, Canada, and China from 1992 to 2011 and comparing them with optical extinction measurements, and with the more limited $\mathrm{PM}_{2.5}$ observations available since 1997. When comparing the optical and mass concentration of aerosols, normalized values are used to account for their different definition.

\section{Study regions and data}

$\mathrm{PM}_{10}$ is more indicative of near-field primary emissions of particulates, whereas the optical extinction is more indicative of regional-scale secondary particles formed over a few days and more involving atmospheric transport and chemistry. $\mathrm{PM}_{2.5}$ is somewhat intermediate between these two cases, i.e., it includes appreciable components of both primary and secondary particles (Fenger, 2009). $\mathrm{PM}_{10}$ and $\mathrm{PM}_{2.5}$ are designed to sample particles with aerodynamic diameters up to the nominal diameter. For example, particles measured by $\mathrm{PM}_{2.5}$ are a subset of particles measured by $\mathrm{PM}_{10}$. Thus there is some overlap between particle measurements of $\mathrm{PM}_{10}$ and $\mathrm{PM}_{2.5}$. Similarly, measurements of $\mathrm{PM}_{10}$ and $\mathrm{PM}_{2.5}$ should include particles less than $1 \mu \mathrm{m}$ - which are linked to optical extinction data (visibility measurements) - so there is also some overlap between the measurements of (a) $\mathrm{PM}_{10}$ and $\mathrm{PM}_{2.5}$ and (b) optical extinction.

In this study, we investigate the long-term variation of optical and mass properties in the northern hemisphere, including China, the US, Canada, and Europe. We use $\mathrm{PM}_{10}$ and $\mathrm{PM}_{2.5}$ data to quantify long-term variation of mass property of atmospheric aerosols. The meteorological visibility is used to characterize the climatic variability of optical extinction of aerosols, in particular, those with diameter less than $1 \mu \mathrm{m}$.

\subsection{Visibility and meteorological data}

This work uses the Global Summary of Day (GSOD) database distributed by the National Climatic Data Center (NCDC), USA (ftp://ftp.ncdc.noaa.gov/pub/data/gsod).
Data from over 9000 stations are typically available. The GSOD data contain 18 surface meteorological parameters derived from synoptic hourly observations: mean temperature, mean dew point, mean sea-level pressure, mean station pressure, daily mean visibility, mean wind speed, maximum sustained wind speed, maximum wind gust, maximum temperature, minimum temperature, precipitation amount, and snow depth. Information is also included on the occurrence of fog, rain/drizzle, snow/ice pellets, hail, thunder, and tornado/funnel clouds.

Visibility, the maximum distance at which an observer can discern the outline of an object against the horizon sky, is reduced mainly by the presence of aerosols and hydrometeors. Eliminating the influence of hydrometeors on visibility allows an estimation of the near-surface optical extinction coefficient of aerosols from long-term observations of visibility (Husar et al., 2000). In this study, we also corrected the impact of relative humidity on visibility according to the methods reported by Che et al. (2007):

$$
V_{\mathrm{i}}=\left\{\begin{array}{c}
\frac{V_{i}^{w}}{0.85}(\mathrm{RH} \leq 30 \%) \\
\frac{V_{\mathrm{i}}^{w}}{(\mathrm{RH}-30 \%) * 0.05+0.85}(30 \%<\mathrm{RH} \leq 40 \%) \\
\frac{V_{i}^{w}}{(\mathrm{RH}-40 \%) * 0.05+0.90}(40 \%<\mathrm{RH} \leq 50 \%) \\
\frac{V_{\mathrm{i}}^{w}}{(\mathrm{RH}-50 \%) * 0.05+0.95}(50 \%<\mathrm{RH} \leq 60 \%) \\
\frac{V_{i}^{w}}{(\mathrm{RH}-60 \%) * 0.05+1.00}(60 \%<\mathrm{RH} \leq 70 \%) \\
\frac{V_{\mathrm{i}}^{w}}{(\mathrm{RH}-70 \%) * 0.03+1.05}(70 \%<\mathrm{RH} \leq 75 \%) \\
\frac{V_{i}^{w}}{(\mathrm{RH}-75 \%) * 0.04+1.20}(75 \%<\mathrm{RH} \leq 80 \%) \\
\frac{V_{\mathrm{i}}^{w}}{(\mathrm{RH}-80 \%) * 0.05+1.40}(80 \%<\mathrm{RH} \leq 85 \%) \\
\frac{V_{i}^{w}}{(\mathrm{RH}-85 \%) * 0.29+1.65}(85 \%<\mathrm{RH} \leq 90 \%)
\end{array}\right.
$$

where $V_{\mathrm{i}}^{w}$ is the inverse of visibility and $V_{\mathrm{i}}$ is the corrected inverse of visibility for relative humidity, which is used in this paper.

Meteorological visibility is observed by manual assessment in China, Europe, and Canada. This was also the case for the US before the 1992. After that, the US used instrument (visibility meter) observation to replace the manual assessment of visibility. This change from manual assessments to instrument observations introduced discontinuity in the data of visibility (Wang et al., 2009). Therefore, for the US, we do not use the manual assessment of visibility but retained the instrument observations to provide detailed information on the relationship between visibility and optical extinction coefficient of aerosols.

In this study, we use the inverse of the visibility to quantify optical extinction of atmospheric aerosols. It has been successfully used to characterize long-term variation of atmospheric aerosols globally over the land from 1973 to 2007 
(Wang et al., 2009). The long-term variability of atmospheric aerosols derived from visibility has been confirmed by numerous independent estimates of atmospheric aerosols using direct measurements (Mitchell et al., 2010; Yoon et al., 2012), satellite retrievals (Lau and Kim, 2010; Dey and Di Girolamo, 2011), radiation measurements (den Outer et al., 2010; Ruckstuhl et al., 2010; Dwyer et al., 2010), and global chemical model simulations (Pozzoli et al., 2011; Chiacchio et al., 2011). Visibility has also been used to quantify longterm variations of haze over Europe (Vautard et al., 2009) and forest fire smoke over Southeast Asia (Field et al., 2009).

The values of optical extinction were averaged into monthly values when comparing with $\mathrm{PM}_{10}$ and $\mathrm{PM}_{2.5}$ data. Quality control of visibility records can be found at Wang et al. (2009). We did not carry out independent quality control of PM10 and $\mathrm{PM}_{2.5}$ records. Before the comparisons, we also normalized both mass concentration and optical extinction by their multi-year averages.

\section{$2.2 \quad \mathrm{PM}_{10}$ data}

\subsubsection{PM $_{10}$ data over the US}

For the US, hourly $\mathrm{PM}_{10}$ measured by the Air Quality System from 1993 to 2010 was obtained via the US Environmental Protection Agency website at: http://www.epa.gov/ ttn/airs/airsaqs/. Data collected from approximately 800 sites were released. In this study, daily $\mathrm{PM}_{10}$ was calculated from the hourly data, from which the monthly values were calculated. The monthly $\mathrm{PM}_{10}$ was regarded reliable only if the daily $\mathrm{PM}_{10}$ values were available for more than 15 days during a month.

We selected 129 sites where reliable monthly $\mathrm{PM}_{10}$ data were available for more than 120 months from 1993 to 2010 . Among the 129 sites, 51 sites were located in urban areas, 60 sites were located in suburban areas, and 18 sites were located in rural areas. See Figs. 1 and 2 for their locations and their site-average $\mathrm{PM}_{10}$ values.

\subsubsection{PM $_{10}$ data over Europe}

Hourly $\mathrm{PM}_{10}$ data over Europe were downloaded from AirBase: http://acm.eionet.europa.eu/databases/airbase/. About 3000 sites in the 39 European countries supplied $\mathrm{PM}_{10}$ data from 1992 to 2009. Among them, 250 sites have more than 120 months of reliable monthly $\mathrm{PM}_{10}$ data, including 148 urban sites, 62 suburban sites, and 40 rural sites. Figs. 1 and 2 show their locations and their site-average $\mathrm{PM}_{10}$ values.

\subsection{3 $\mathrm{PM}_{10}$ data over China}

Daily $\mathrm{PM}_{10}$ data over China were calculated from the daily Air Pollution Index (API) (from noon to noon), which were released by the Data Center of Ministry of Environmental Protection of the People's Republic of China: http:// datacenter.mep.gov.cn/ (in Chinese). Hourly $\mathrm{PM}_{10}$ data were
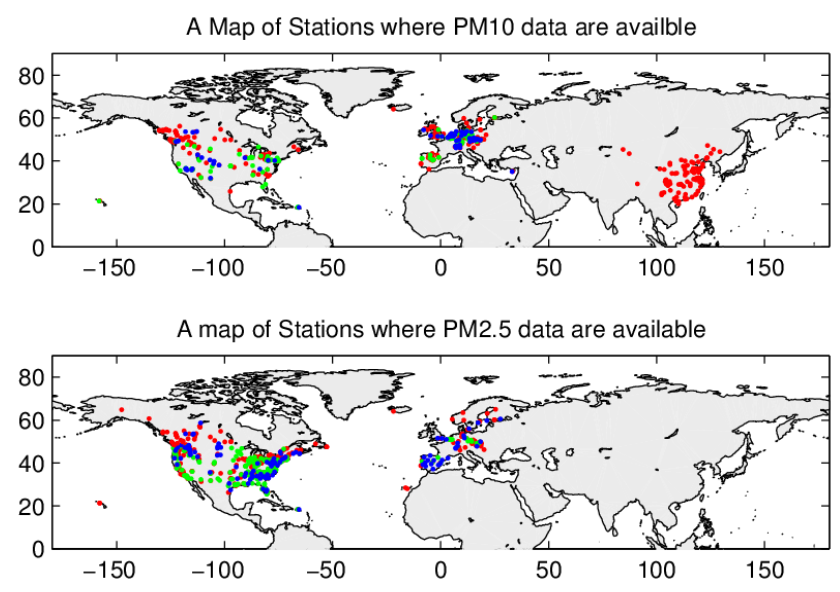

Fig. 1. (Top panel) A map of stations over China, Europe, US, and Canada (red points: urban sites, green points: suburban sites, and blue points: rural sites). Europe and US stations have more than 120 months of data of $\mathrm{PM}_{10}$ during the study period, while China and Canada stations have more than 60 months of data of $\mathrm{PM}_{10}$ available during the study period. (Bottom panel) A map of stations over Europe, the US, and Canada (red points: urban sites, green points: suburban sites, and blue points: rural sites) where $\mathrm{PM}_{2.5}$ data are available for more than 60 months from 1998 to 2010.

collected at several sites in each city, for example, 8 sites for Beijing (Zhu et al., 2011). Data for $\mathrm{PM}_{10}, \mathrm{NO}_{2}$, and $\mathrm{SO}_{2}$ were averaged to daily values and normalized to an API for each constituent. The highest of these API values were used to estimate the city API and released to the public.

The daily $\mathrm{PM}_{10}$ values were estimated from API equations, assuming $\mathrm{PM}_{10}$ was the primary pollutant and may be overestimated if the API was determined from $\mathrm{SO}_{2}$ or $\mathrm{NO}_{2}$ concentrations. We evaluated this uncertainty at 31 major cities in China, including province capitals and four municipalities. Annual averaged PM $_{10}$ values from 2003 to 2009 at the 31 mega-cities are available from the annual report of the National Bureau of Statistics of China (available at http://www.stats.gov.cn/tjsj/ndsj/, in Chinese). We calculated their city-average $\mathrm{PM}_{10}$ values and compared them to those calculated from the API. The results are shown in Fig. 3. The overestimation (bias) is less than $2 \%$, with $R^{2}=0.995$. $\mathrm{PM}_{10}$ is the primary pollutant for more than $80 \%$ of the conditions in most cities. The cities in China range from those most polluted to those least polluted (Figs. 2 and 3). Therefore, we believe our $\mathrm{PM}_{10}$ values calculated from the API are reliable. There are some cities where the API calculated $\mathrm{PM}_{10}$ values are a little less than those averaged from the measurements. This is because when the calculated API is larger than 500, the API is set to 500 and that value is reported to the public. However, the observed values of $\mathrm{PM}_{10}$ are only released annually for the 31 major cities from 2003 to 2009 .

API data are available at http://datacenter.mep.gov.cn/ for approximately 120 Chinese cities from 2000 to 2011. Eightysix cities were selected where reliable monthly $\mathrm{PM}_{10}$ data are 


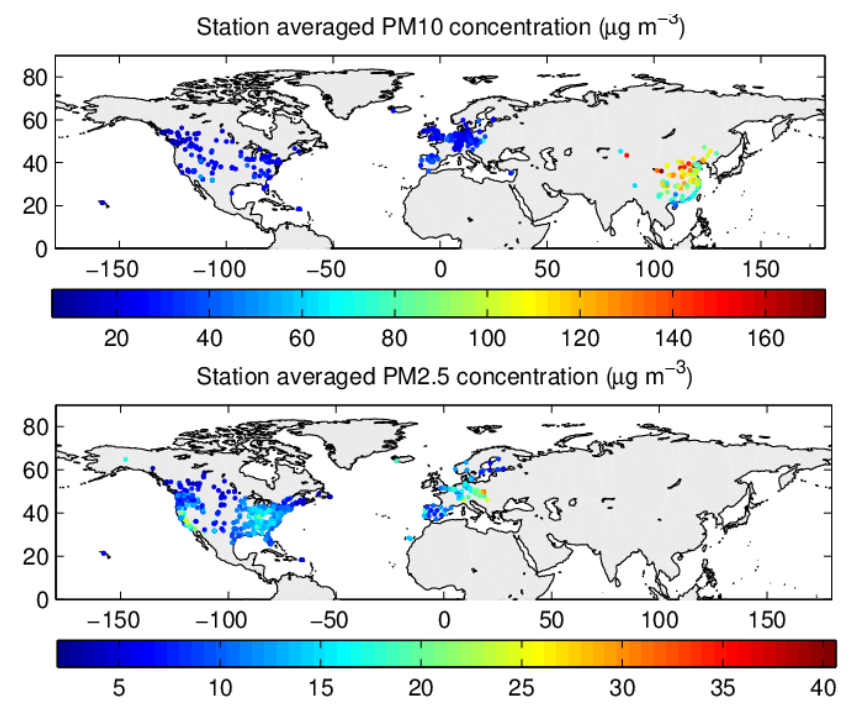

Fig. 2. A map of station multi-year averaged $\mathrm{PM}_{10}$ and $\mathrm{PM}_{2.5}$ mass concentration (unit: $\mu \mathrm{g} \mathrm{m}^{-3}$ ).

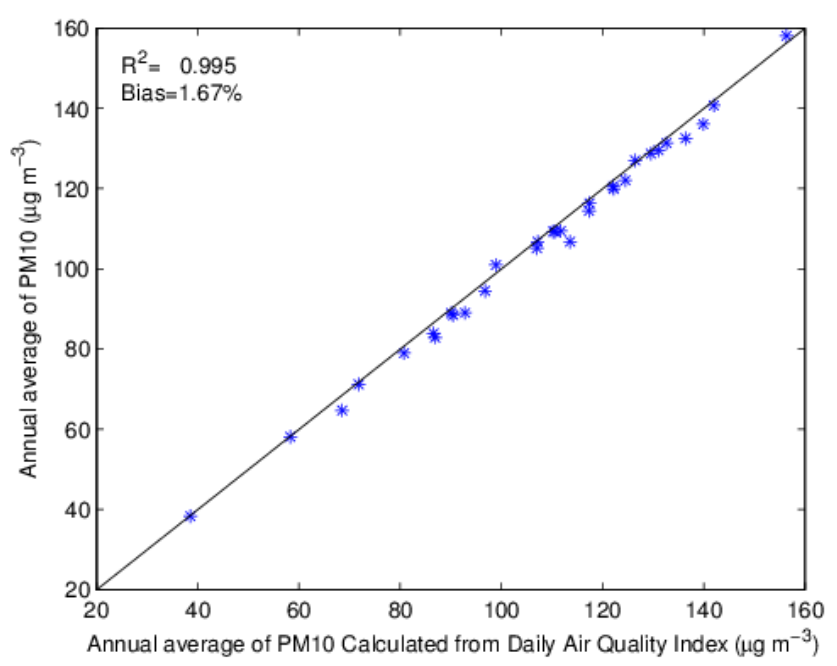

Fig. 3. The comparison of site-average $\mathrm{PM}_{10}$ calculated from Air Quality Index and those averaged from $\mathrm{PM}_{10}$ measurements from 2003 to 2009 in 31 major cities in China.

available for more than 60 months from 2000 to 2011 (See Fig. 2), and half of them have $\mathrm{PM}_{10}$ data for more than 120 months.

\subsection{4 $\mathrm{PM}_{10}$ data over Canada}

Hourly $\mathrm{PM}_{10}$ data in Canada were collected through the National Air Pollution Surveillance (NAPS) Network: http: //www.etc-cte.ec.gc.ca/napsdata/Default.aspx. The NAPS Network was established in 1969 as a joint program of the federal and provincial governments to monitor and assess ambient air in Canadian urban centres. The goal of the NAPS program is to provide accurate and long-term air quality data of a uniform standard throughout Canada. $\mathrm{PM}_{10}$ data are available from 1992 to 2009 at the above website. There were 110 sites that reported $\mathrm{PM}_{10}$ to NAPS, and of these about 64 sites have more than 60 months of reliable monthly $\mathrm{PM}_{10}$ data.

NAPS classified its stations into six types, Agricultural Rural (A), Commercial (C), Forested Rural (F), Industrial (I), Residential (R), and Undeveloped Rural (U). For consistency with other regions, we reorganized them into three basic types (Fig. 1): C and R are urban types, A, F and U are rural stations, and I is the suburban type. Most of the Canadian stations are located in urban areas, i.e., 57 of 64 . The other 7 stations are 5 in rural regions and 2 in suburban. The detailed site information can be found in Figs. 1 and 2.

\section{$2.3 \quad \mathbf{P M}_{2.5}$ data}

$\mathrm{PM}_{2.5}$ data were available for the US, Canada, and European countries. China generally has not taken routine $\mathrm{PM}_{2.5} \mathrm{ob}-$ servations, but Beijing has started in 2012.

\subsubsection{PM $_{2.5}$ data over US}

The US hourly $\mathrm{PM}_{2.5}$ data are available from http://www. epa.gov/ttn/airs/airsaqs/. Approximately 900 stations reported $\mathrm{PM}_{2.5}$ data from 1993 to 2010. A total of 406 stations were selected where reliable monthly $\mathrm{PM}_{2.5}$ data were available for more than 60 months from 1998 to 2010, including 160 urban stations, 160 suburban stations, and 86 rural stations. See Figs. 1 and 2 for detailed information.

\subsection{2 $\mathrm{PM}_{2.5}$ data over Europe}

Hourly PM $_{2.5}$ data for Europe from 1998 to 2009 are available at http://acm.eionet.europa.eu/databases/airbase/. About 700 stations reported $\mathrm{PM}_{2.5}$ data. In this study, 98 stations were selected where reliable monthly $\mathrm{PM}_{2.5}$ data were available for more than 60 months from 1998 to 2009, including 53 urban stations, 17 suburban stations, and 28 rural stations. Figs. 1 and 2 provide detailed information.

\subsection{3 $\mathrm{PM}_{2.5}$ data over Canada}

Hourly $\mathrm{PM}_{2.5}$ data in Canada were collected through the NAPS Network: http://www.etc-cte.ec.gc.ca/napsdata/ Default.aspx. $\mathrm{PM}_{2.5}$ data are available from 1995 to 2009. A total of 159 sites reported $\mathrm{PM}_{2.5}$ to NAPS, and about 56 sites have more than 60 months of reliable $\mathrm{PM}_{2.5}$ data. Most of the Canadian stations are located in urban areas, i.e., 48 of 56. The other 8 stations are 7 in rural region and 1 in suburban. The site information can be found in Figs. 1 and 2 .

\section{4 $\mathrm{PM}_{10}$ and $\mathrm{PM}_{2.5}$ measurement methods and data consistency}

Many measurement techniques have been used to measure $\mathrm{PM}_{10}$ and $\mathrm{PM}_{2.5}$. The measurement technique to measure 
$\mathrm{PM}_{10}$ and $\mathrm{PM}_{2.5}$ at each station can be found at the above mentioned websites except for those in China. Intercomparison of the measurements can be found at Allen et al. (1997), Price et al. (2003), and Williams et al. (2000).

Reference methods for $\mathrm{PM}_{10}$ and $\mathrm{PM}_{2.5}$ mass concentrations includes the European reference method (EN 12341 NORM) and the US EPA reference method for $\mathrm{PM}_{10}$ (http://www.epa.gov/ttn/emc/promgate/m-201.pdf). Alternative methods for $\mathrm{PM}_{10}$ or $\mathrm{PM}_{2.5}$ may introduce positive and negative sampling artifacts comparing with the reference methods, depending on chemical composition of the aerosols, as well as meteorological conditions (Putaud et al., 2004, 2010).

One of the primary factors resulting in data consistency is the relative humidity $(\mathrm{RH})$ requirement of different measurement methods. For example, at a continental site (Putaud et al., 2004), $\mathrm{PM}_{10}$ and $\mathrm{PM}_{2.5}$ measurements at $50 \%$ RH may be $9 \%$ and $7 \%$ higher than those at $20 \%$ RH. Studies have shown that the routine tapered element oscillating microbalance method underestimates $\mathrm{PM}_{10}$ measurements by up to $35 \%$, when compared with the European reference method (Allen et al., 1997; Van Dingenen et al., 2004). This underestimation is more severe in winter than in summer. These measurement differences explain the differences between modeled and measured $\mathrm{PM}_{10}$ and $\mathrm{PM}_{2.5}$ (Tsyro, 2005). Other factors that may introduce data disconsistency include land-use around a measurement station as well as change in station location. For example, changes of the location of observations in Beijing have been reported (Andrews, 2008).

To keep data consistent, we only use data from one measurement method for each site. However, we do not have information on the method of measurement of $\mathrm{PM}_{10}$ used at the Chinese sites, reducing our confidence in these $\mathrm{PM}_{10}$ data.

\section{Results}

\subsection{Climatology and long-term trends of $\mathrm{PM}_{10}$}

As for multi-year average of $\mathrm{PM}_{10}$, China's urban areas are the most polluted, while Canada is the least polluted of the regions studied (Table 1 and Fig. 2). Table 1 also demonstrates that there are no substantial differences in the $\mathrm{PM}_{10}$ concentration over urban, suburban, and rural areas in Europe and the US, most likely because urban areas in European countries and the US are lightly polluted in terms of $\mathrm{PM}_{10}$ compared to urban areas in China.

$\mathrm{PM}_{10}$ substantially decreased in Europe, the US, and Canada from 1992 to 2011 (Fig. 4). $\mathrm{PM}_{10}$ in Europe decreased by $13 \mu \mathrm{g} \mathrm{m}^{-3}$ (44\%), averaged from 250 sites from 1992 to 2009, with peaks in 1996, 2003, and 2006. These peak values may be caused by dust from North African deserts associated with drought (Mahowald wt al., 2007). They were not reproduced in recent modeling studies, although most models predicted a long-term reduction of $\mathrm{PM}_{10}$
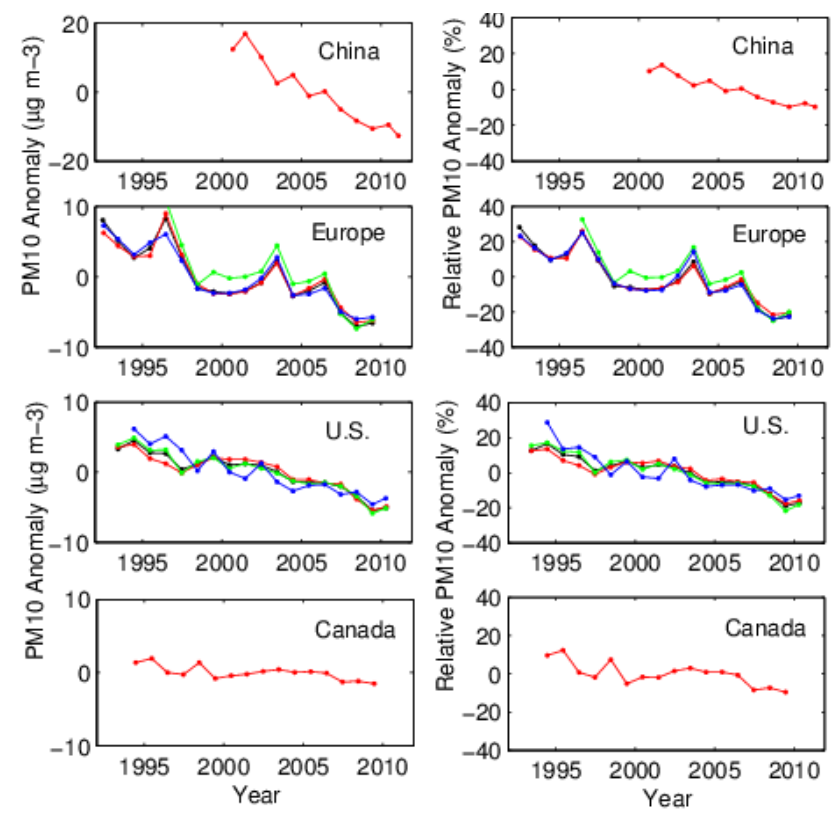

Fig. 4. Annual anomalies (left) of $\mathrm{PM}_{10}$ and their relative anomalies (normalized by multi-year averaged $\mathrm{PM}_{10}$ value from each site) (right). Black lines represent averages over total sites, red lines represent urban averages, green lines represent suburban averages, and blue lines represent rural averages. Multi-year regional averages of $\mathrm{PM}_{10}$ can be found in Table 1 .

similar to that observed during the study period (Chiacchio et al., 2010).

$\mathrm{PM}_{10}$ in the US decreased by about $9 \mu \mathrm{g} \mathrm{m}^{-3}$ (33\%), averaged over 129 sites from 1993 to 2010, with no large differences in the long-term trends in the urban, suburban, and rural areas of Europe and the US (Fig. 4), implying that emission controls worked equally well in all areas (Murphy et al., 2011). It decreased in Canada by about $2.3 \mu \mathrm{g} \mathrm{m}^{-3}$ (15\%), averaged over 64 sites from 1994 to 2009 . The more recent reduction in China, by $32 \mu \mathrm{g} \mathrm{m}^{-3}(26 \%)$, is attributed to emission controls, as energy consumption has increased dramatically since 2000 (Fig. 5).

\subsection{Climatology and long-term trends of $\mathbf{P M}_{2.5}$}

$\mathrm{PM}_{2.5}$ data are available from about 550 sites in Europe, the US, and Canada from 1997 to 2010. On average, $\mathrm{PM}_{2.5}$ in Europe has been a little higher than in the US, while in Canada it has been one-third as much (Table 1 and Fig. 2). Generally, urban and suburban areas have similar $\mathrm{PM}_{2.5}$ values, while values in rural areas are much less. Their variations (Fig. 6) are consistent with those of $\mathrm{PM}_{10}$ (Fig. 4), but with amplified inter-annual variability.

Emission from wildfire is a major source of particles with diameters less than $2 \mu \mathrm{m}$ (Barnaba et al., 2011; Crounse et al., 2009; Reid et al., 2005). Wildland fire emissions showed large interannual variability (Giglio et al., 2006; van der Werf 
Table 1. Multi-year regional averages of $\mathrm{PM}_{10}$ and $\mathrm{PM}_{2.5}$ (unit: $\mu \mathrm{g} \mathrm{m}{ }^{-3}$ ) with a standard deviation in the study regions. The averages of all the available data are shown in the third column (Total). The numbers in the brackets of the last four columns show the number of the stations where data are available for the averages. Values for each site can be found at Fig. 2.

\begin{tabular}{llllll}
\hline & Region (time period) & Total & Urban & Suburban & Rural \\
\hline $\mathrm{PM}_{10}$ & China (2000-2011) & & $96.5 \pm 26.4(86)$ & & \\
& Europe (1992-2009) & $28.9 \pm 8.6(250)$ & $30.6 \pm 8.4(148)$ & $28.3 \pm 7.5(62)$ & $24.0 \pm 9.2(40)$ \\
& US (1993-2010) & $27.0 \pm 7.9(129)$ & $27.6 \pm 8.1(51)$ & $26.2 \pm 7.2(60)$ & $28.4 \pm 9.8(18)$ \\
& Canada (1993-2009) & & $15.5 \pm 5.2(57)$ & & \\
$\mathrm{PM}_{2.5}$ & Europe (1998-2009) & $15.8 \pm 6.5(98)$ & $17.5 \pm 5.9(53)$ & $17.8 \pm 4.7(17)$ & $11.3 \pm 6.6(28)$ \\
& USA (1998-2010) & $12.2 \pm 3.5(406)$ & $12.5 \pm 3.5(160)$ & $12.7 \pm 3.2(160)$ & $10.0 \pm 3.4(86)$ \\
\cline { 2 - 6 } & Canada (1995-2009) & $5.6 \pm 2.3(56)$ & $5.6 \pm 1.7(48)$ & & $3.8 \pm 1.5(7)$ \\
\hline
\end{tabular}
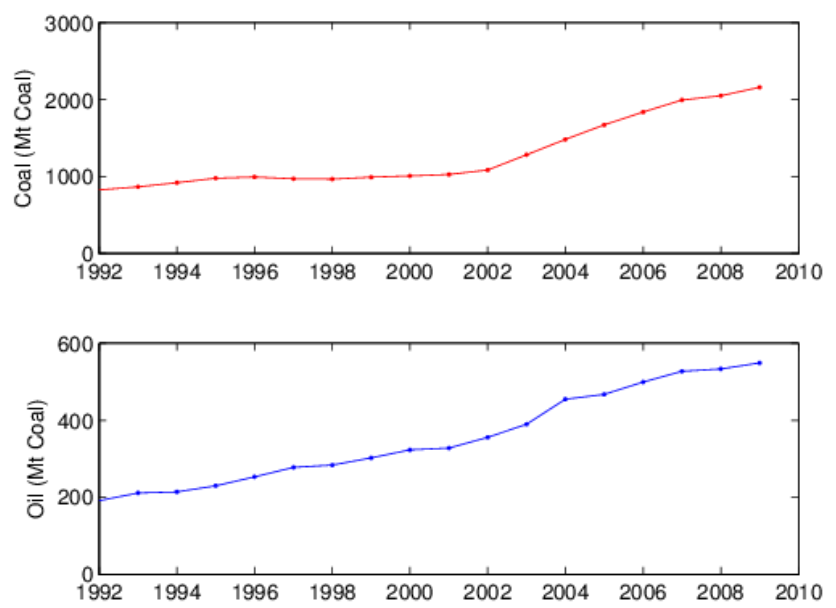

Fig. 5. Total coal and oil consumption in China from 1992 to 2009 (unit: million ton coal, data source: National Bureau of Statistics of China, available at http://www.stats.gov.cn/tjsj/ndsj/, in Chinese).

et al., 2006). The 2003 European summer heat wave caused the record-breaking forest fires in Portugal (Garcia-Herrera et al., 2010; Trigo et al., 2006), which contributed to the $\mathrm{PM}_{2.5}$ in 2003. Emissions of wildfires in Europe in 2003 caused wildland fire emission to be about 50 times as large as in 2008 (Rosa et al., 2011).

The duration of the $\mathrm{PM}_{2.5}$ data is slightly shorter than that of $\mathrm{PM}_{10}$ and no $\mathrm{PM}_{2.5}$ data are available for China. For the period when both $\mathrm{PM}_{10}$ and $\mathrm{PM}_{2.5}$ are available elsewhere, linear trends of $\mathrm{PM}_{2.5}$ are $-9 \%$ per decade (Europe), $-18 \%$ per decade (US), and $-8 \%$ per decade (Canada), while $\mathrm{PM}_{10}$ has trends of $-15 \%$ per decade (Europe), $-23 \%$ per decade (US), and $-7 \%$ per decade (Canada). The negative trends of $\mathrm{PM}_{2.5}$ in Europe and the US are substantially less in magnitude than those of $\mathrm{PM}_{10}$.

Most of data used in this study are located in urban areas. The decreasing trends of $\mathrm{PM}_{2.5}$ reported here are consistent with those at remote sites in Europe (Barmpadimos et al., 2011; Barmpadimos et al., 2012; Cusack et al., 2012), and in the US (Murphy et al., 2011).
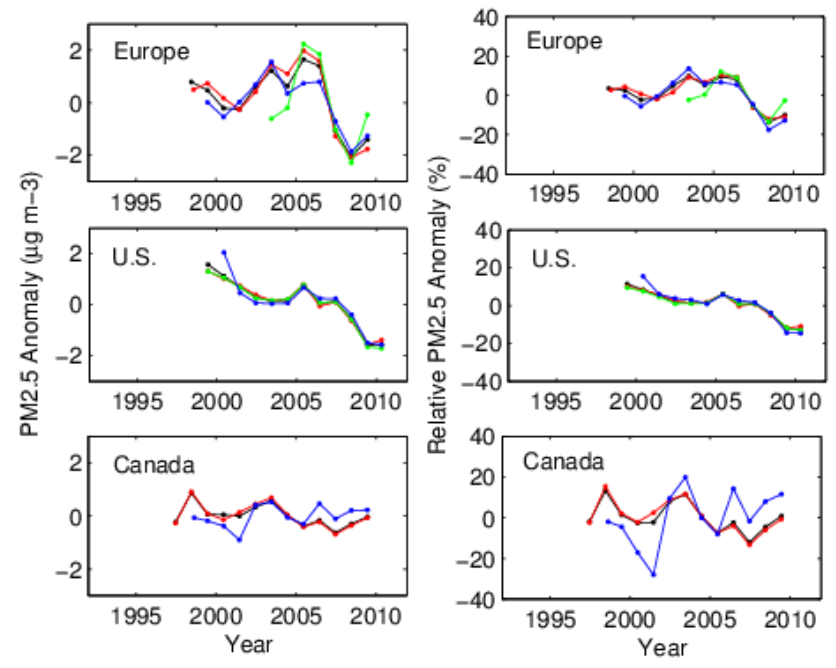

Fig. 6. Annual anomalies (left) of $\mathrm{PM}_{2.5}$ and their relative anomalies (normalized by multi-year-averaged $\mathrm{PM}_{2.5}$ value from each site). Black lines represent averages over total sites, red lines represent urban averages, green lines represent suburban averages, and blue lines represent rural averages. Multi-year regional averages of $\mathrm{PM}_{2.5}$ can be found in Table 1 .

\subsection{Contrasting trends of mass and optical properties of aerosols}

The variations of $\mathrm{PM}_{10}, \mathrm{PM}_{2.5}$, and optical extinction of aerosols in Europe, the US, and Canada are compared using $\mathrm{PM}_{10}$ sites where meteorological visibility also has been measured within $10 \mathrm{~km}$. It is also the case for $\mathrm{PM}_{2.5}$. For the cities in China, we paired the $\mathrm{PM}_{10}$ and visibility using the city name because the Air Pollution Indices (APIs) are averaged from many sites in a city.

Monthly $\mathrm{PM}_{10}, \mathrm{PM}_{2.5}$, and optical extinction were closely correlated (Figs. 7 and 8). Both $\mathrm{PM}_{10}$ and optical extinction have the largest seasonal variations in China. The correlation coefficients between $\mathrm{PM}_{10}$ and optical extinction are the strongest in China. The concentrations of $\mathrm{PM}_{10}$ in the US and in Canada are very low as is also optical extinction and 

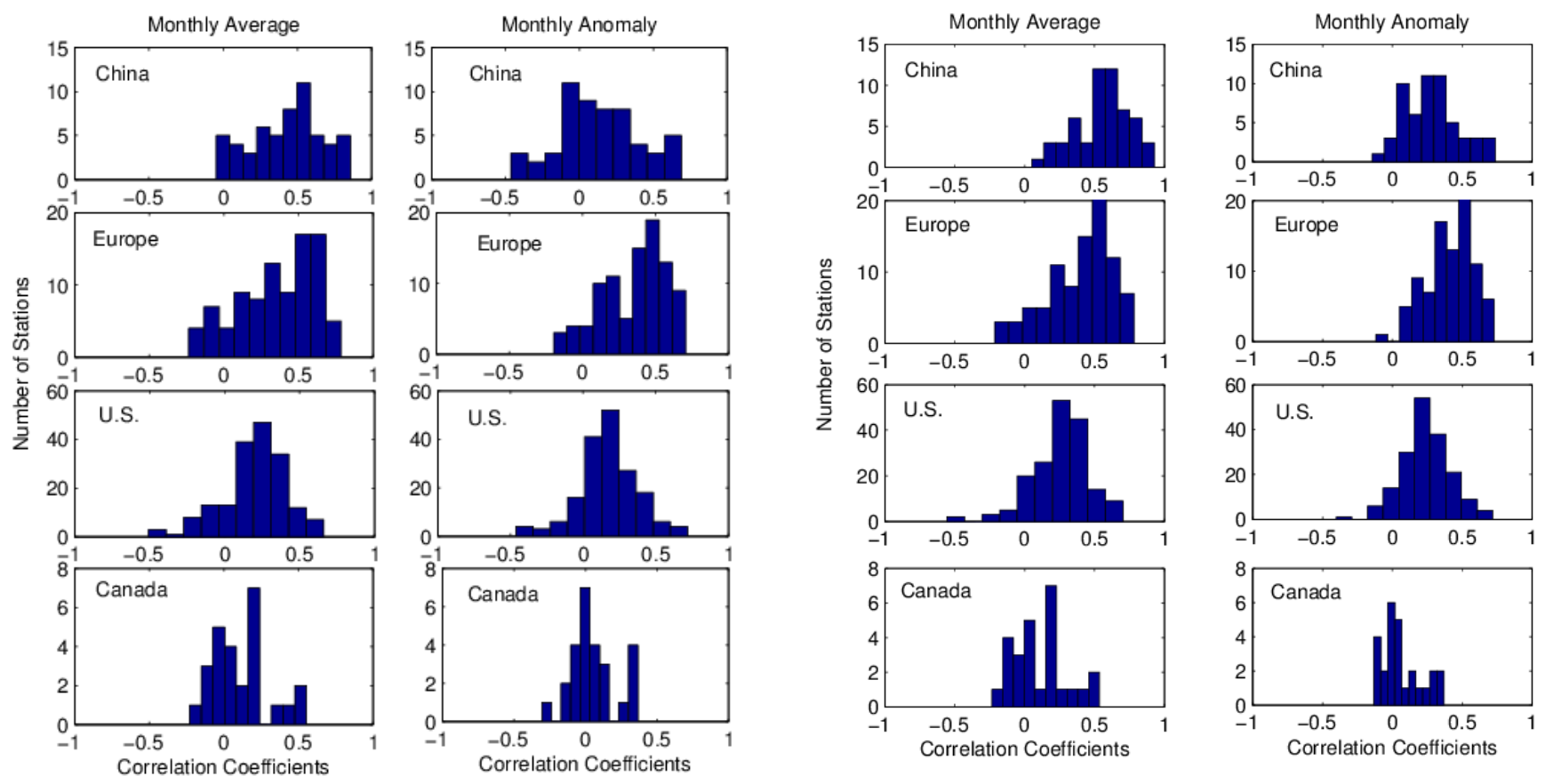

Fig. 7. Left column: the histograms of correlation coefficients, computed at each station, between monthly averages of $\mathrm{PM}_{10}$ and optical extinction coefficients (inverse of visibility); right column: same as left column except that correlation coefficients are between monthly anomalies. Regions are as indicated in each panel. Data used here are the same as those used in Figs. 9 and 10.

both have low seasonal variations (Table 1) and much lower correlation coefficients, impacted by the measurement uncertainty.

High correlation coefficients between monthly $\mathrm{PM}_{10}$ and optical extinction occur because atmospheric aerosols (Mahowald et al., 2007; van Oldenborgh et al., 2010) and $\mathrm{PM}_{10}$ (Barmpadimos et al., 2011) are predominately determined by meteorological conditions at this time scale. However, long-term trends of atmospheric aerosols are little impacted by changing atmospheric circulation (Chiacchio et al., 2011; Hirdman et al., 2010; van Oldenborgh et al., 2010) but rather are dominated by emissions (Fenger, 2009; Murphy et al., 2011).

The long-term trends of $\mathrm{PM}_{10}$ and optical extinction are opposite in China, the US, and Canada (Fig. 9). From 1993 to 2010, optical extinction increased by $7 \%$ over the US and by $10 \%$ over Canada in spite of a substantial reduction of $\mathrm{PM}_{10}$ in these two regions. The reduction of optical extinction over Europe of $5 \%$ is also much less than the $44 \%$ reduction in $\mathrm{PM}_{10}$. Fig. 9 show that optical extinction of aerosols increased by $20 \%$ in China from 2000 to 2005, and then decreased slightly, resulting in an overall increase of $18 \%$ from 2000 to 2011.

Measures of aerosols reported here $\left(\mathrm{PM}_{2.5}, \mathrm{PM}_{10}\right.$, optical extinction) are near surface measurements. Other widely

Fig. 8. Same as Fig. 7 except that the long-term trends were removed from the monthly averages and monthly anomalies (seasonal cycle removed) of $\mathrm{PM}_{10}$ and optical extinction coefficients (inverse of visibility).

used measures of aerosols are column total, i.e., aerosol optical depth derived from satellite observations. Information on aerosol profile and atmospheric mixing layer height is needed to relate these surface measures to column total measures (Schaap et al., 2009), which may have substantial seasonal variations. However, their inter-annual variations should be very small. Therefore, it is reasonable to compare longterm trends of these surface measures to column total measures under the assumption that the inter-annual variation of aerosol profile and atmospheric mixing layer height can be ignored.

We find that the increase of optical extinction in China is consistent with the increase of $\mathrm{SO}_{2}$ (an important precursor of particles with diameter less than $1 \mu \mathrm{m}$ ) estimated from satellite retrievals (Wang et al., 2010; Lyapustin et al., 2011; Itahashi et al., 2012), ground-based measurements (Lu et al., 2010), and model simulations (Lu et al., 2010). In particular, satellite-derived aerosol optical depth (Fig. 4a of Itahashi et al., 2012) and modeled $\mathrm{SO}_{2}$ emission (figure $2 \mathrm{Lu}$ et al., 2010) show nearly same variability of optical extinction of aerosols derived from visibility. The cessation of the rapid increase since 2005 has been attributed to the application of flue-gas desulfurization devices in power plants in response to new Chinese policy (Lu et al., 2010). This fluegas desulphurization technique was used by most European, US and Canadian power stations before the start of the study period and therefore its introduction did not impact the longterm variation of aerosols in Europe, US and Canada over 


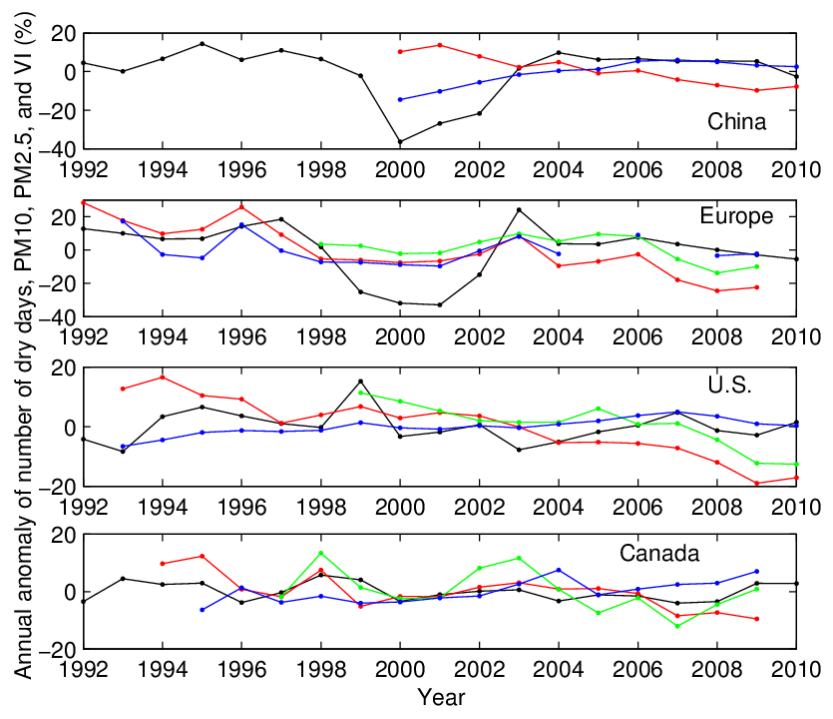

Fig. 9. Annual anomaly of normalized number of dry days (black), $\mathrm{PM}_{10}$ (red), $\mathrm{PM}_{2.5}$ (green), and optical extinction coefficients (inverse of visibility, blue) averaged from sites where $\mathrm{PM}_{10}$ data are available for more than 120 months for Europe and the US and for more than 60 months for China and Canada.

the period studied (Cooper et al., 1997; Nan, 1994). Several of China's mega-cites announced other measures (Wang and Chen, 2010) to control air pollution after 2005.

\subsection{Precipitation Impacts on Mass and Optical Proper- ties of Aerosols}

Besides transport to other regions, aerosols are removed from the atmosphere through wet and dry deposition (Andronache, 2003). In Europe, anthropogenic aerosols are removed mostly by rain $(95 \%)$ and only $5 \%$ is removed by dry deposition (Aan de Brugh et al., 2011). Monsoon rainfall has been reported to be a dominating factor controling concentrations of atmospheric aerosols (Hyvärinen et al., 2011; Lawrence and Lelieveld, 2010).

Figure 9 shows that the variation in the number of precipitation days agrees more with the long-term variation of optical extinction than the concentrations of $\mathrm{PM}_{10}$, as expected from these removal processes. Dry days are defined as the number of days without effective precipitation (rain gauge reading being larger than $0.1 \mathrm{~mm}$ ) in a year. Where both precipitation and visibility were observed at a weather station, we paired them with a $\mathrm{PM}_{10}$ station using the same method discussed in Sect. 3.3. More numerous dry days imply less frequent removal of aerosols by rainfall as well as greater risk of wildfires, both of which result in higher aerosol concentrations in the atmosphere. The inter-annual variations of optical extinction over China and Europe agree well with the occurrence of dry days, with averaged correlation coefficients of 0.93 and 0.66 , partly because both aerosols and dry days have large inter-annual variability (Fig.10). Dry days

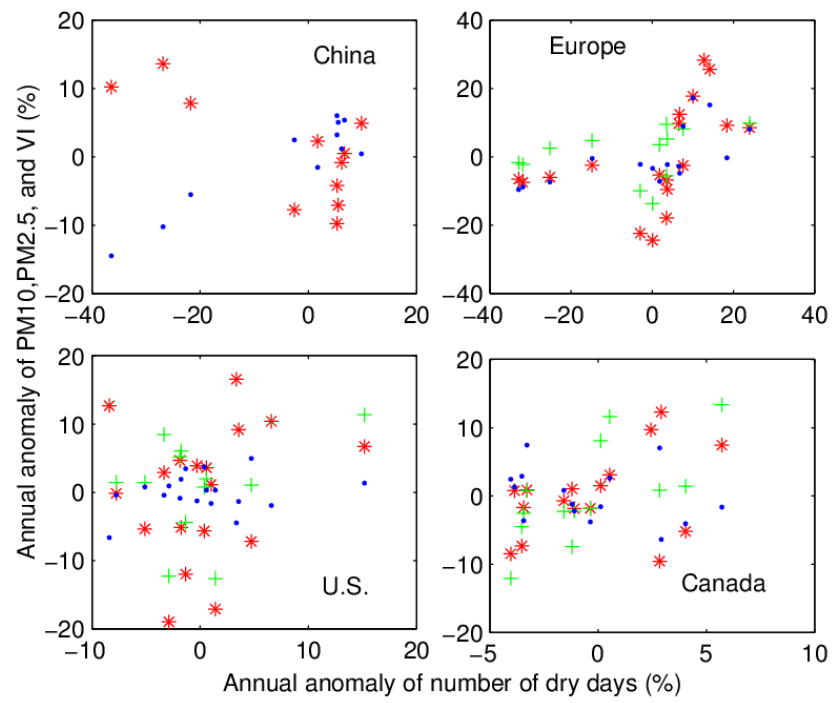

Fig. 10. Scatterplots of regional averaged annual anomalies of $\mathrm{PM}_{10}$ (red star), $\mathrm{PM}_{2.5}$ (green cross), and aerosol optical extinction (inverse of visibility, blue dot) as a function of annual anomalies of number of dry days in China, Europe, the US, and Canada. Data used are same to Fig. 9. The correlation coefficients between optical extinction and dry days are 0.93 (China), 0.66 (Europe), 0.23 (the US) and -0.32 (Canada). The correlation coefficients between $\mathrm{PM}_{10}$ and dry days are -0.73 (China), 0.47 (Europe), 0.20 (the US) and 0.42 (Canada). The correlation coefficients between $\mathrm{PM}_{2.5}$ and dry days are 0.29 (Europe), 0.29 (the US) and 0.68 (Canada).

vary less in the US and Canada (Fig. 10) and their contribution to the variation of aerosols is expected to be small. Inter-annual variation of optical extinction is consistent with the occurrence of dry days in the US. However, the correlation between $\mathrm{PM}_{2.5}$ and number of dry days is higher in Canada (Fig. 10).

\section{Conclusions}

This study compares the long-term variation of mass and optical properties of atmospheric aerosols over the Northern Hemisphere, including China, the US, Canada and Europe. Contrasting trends of mass and optical properties were found from 1992 to 2011. In particular, this synthesis of observational data on the mass and optical properties of aerosols from Europe, the US, Canada, and China over the past two decades shows that $\mathrm{PM}_{10}$ has decreased substantially over Europe, the US, and Canada from 1992 to 2010 and over China's urban areas from 2000 to 2011. The duration of the $\mathrm{PM}_{2.5}$ data is less than for $\mathrm{PM}_{10}$, but when both $\mathrm{PM}_{2.5}$ and $\mathrm{PM}_{10}$ data were available, the decreasing trends of $\mathrm{PM}_{2.5}$ were substantially less than those of $\mathrm{PM}_{10}$ in Europe and the US. Optical extinction increased in the US and Canada. It increased by $20 \%$ over China's urban areas from 2000 to 2005 but then slightly decreased. 
There are numerous independent studies supporting the long-term trend of optical extinctions of atmospheric aerosols derived from meteorological visibility observations. In particular, satellite-derived AOD (figure $4 \mathrm{a}$ of Itahashi et al., 2012) and modeled $\mathrm{SO}_{2}$ (Fig. 2 Lu et al., 2010) show the nearly same variability as optical extinction of aerosols derived from visibility in China. The cessation of the rapid increase since 2005 has been attributed to the application of flue-gas desulfurization devices in power plants in response to new Chinese policy (Lu et al., 2010). The longterm variability of optical extinction derived from visibility has been confirmed by numerous independent estimates of atmospheric aerosols using direct measurement (Mitchell et al., 2010; Yoon et al., 2012), satellite retrievals (Lau and Kim, 2010; Dey and Di Girolamo, 2011), radiation measurements (den Outer et al., 2010; Ruckstuhl et al., 2010; Dwyer et al., 2010), and global chemical model simulations (Pozzoli et al., 2011; Chiacchio et al., 2011).

These results indicate that although mass concentration of atmospheric aerosols has substantially decreased, optical extinction of aerosols has either decreased less or has increased, indicating that fine particles increased or decreased less, as optical extinction is sensitive to particles of sizes less than $1 \mu \mathrm{m}$. The number of these particles can be large, and they are especially important for their impact on human health (Fenger, 2009).

The reason for the increase of optical extinction (or atmospheric aerosols) has been proposed as more anthropogenic emission of atmospheric aerosols (Myhre, 2009), and in particular those from more sulphate emissions from fossil fuels in developing countries, such as China and India (Wang et al., 2009). Since 2005 in China, there has been a decline in the rate of increase that is likely due to the application of flue gas desulphurization (Lu et al., 2010). Another reason suggested is an increase of forest fires (Yoon et al., 2012). Anthropogenic aerosols has increased substantially since preindustrial times (Tsigaridis et al., 2006).

Although fine particles with diameter less than $1 \mu \mathrm{m}$ account for but a small part of total mass of aerosols, they are very efficient in light extinction. Evidently, the ratio of efficiently-scattering atmospheric particles (Hand and Malm, 2007; Hoff and Christopher, 2009) to total particles has increased in all of the regions studied. A recent study consistent with our results shows that the relative increase in anthropogenic black carbon that has a particle size less than $1 \mu \mathrm{m}$ and is efficient in optical extinction, is much larger than the overall increase in the anthropogenic abundance of aerosols (Myhre, 2009). This increase is important for climate, affecting the global circulation and hydrological cycle (Menon et al., 2002; Ramanathan et al., 2007).

Providing accurate estimates of long-term trends of global atmospheric aerosols is difficult. Satellite based observations provide retrievals of atmospheric aerosols. However, these trends may be very different between satellites. For example, trends derived from MODIS (Moderate Resolution Imag- ing Spectroradiometer) substantially differ from those from MISR (Multi-angle Imaging SpectroRadiometer) (Zhang and Reid, 2010) and AVHRR (Advanced Very High Resolution Radiometer) (Zhao et al., 2008). Besides shortcomings of the algorithms, small satellite sensor calibration uncertainties of $<2 \%$ can lead to spurious conclusions about longterm aerosol trends (Levy et al., 2010). For example, Terra's global AOD bias changed with time, so it gave an overestimation (by $\sim 0.005$ ) before 2004, but an underestimation by a similar magnitude after (Levy et al., 2010). The year-toyear variability of aerosols is generally underestimated by state-of-the-art chemistry and transport models (Colette et al., 2011) and more should be done with these models to obtain accurate estimates of long-term variation of atmospheric aerosols (Kukkonen et al., 2012).

Acknowledgements. Kaicun Wang was jointly funded by the Global Change Key Research Project (2012CB955302) and the National Natural Science Foundation of China (41175126). Robert E. Dickinson was supported by the Department of Energy (DE-FG02-01ER63198). NCAR is sponsored by the National Science Foundation. We thank Gerard Jennings and Roger Timmis for their thorough review and insightful comments on this paper.

Edited by: R. MacKenzie

\section{References}

Aan de Brugh, J. M. J., Schaap, M., Vignati, E., Dentener, F., Kahnert, M., Sofiev, M., Huijnen, V., and Krol, M. C.: The European aerosol budget in 2006, Atmos. Chem. Phys., 11, 1117-1139, doi:10.5194/acp-11-1117-2011, 2011.

Allen, G., Sioutas, C., Koutrakis, P., Reiss, R., Lurmann, F. W., and Roberts, P. T.: Evaluation of the TEOM(R) method for measurement of ambient particulate mass in urban areas, J. Air Waste Manage. Assoc., 47, 682-689, 1997.

Andreae, M. O., Hegg, D. A., and Baltensperger, U.: Sources and Nature of Atmospheric Aerosols, in: Aerosol Pollution Impact on Precipitation, edited by: Levin, Z., and Cotton, W. R., Springer Netherlands, 45-89, 2009.

Andrews, S. Q.: Inconsistencies in air quality metrics: 'Blue Sky' days and $\mathrm{PM}_{10}$ concentrations in Beijing, Environ. Res. Lett., 3, 034009, doi:10.1088/1748-9326/3/3/034009, 2008.

Andronache, C.: Estimated variability of below-cloud aerosol removal by rainfall for observed aerosol size distributions, Atmos. Chem. Phys., 3, 131-143, doi:10.5194/acp-3-131-2003, 2003.

Barmpadimos, I., Hueglin, C., Keller, J., Henne, S., and Prévôt, A. S. H.: Influence of meteorology on $\mathrm{PM}_{10}$ trends and variability in Switzerland from 1991 to 2008, Atmos. Chem. Phys., 11, 18131835, doi:10.5194/acp-11-1813-2011, 2011.

Barmpadimos, I., Keller, J., Oderbolz, D., Hueglin, C., and Prévôt, A. S. H.: One decade of parallel fine $\left(\mathrm{PM}_{2.5}\right)$ and coarse $\left(\mathrm{PM}_{10}-\mathrm{PM}_{2.5}\right)$ particulate matter measurements in Europe: trends and variability, Atmos. Chem. Phys., 12, 3189-3203, doi:10.5194/acp-12-3189-2012, 2012.

Barnaba, F., Angelini, F., Curci, G., and Gobbi, G. P.: An important fingerprint of wildfires on the European aerosol load, 
Atmos. Chem. Phys., 11, 10487-10501, doi:10.5194/acp-1110487-2011, 2011.

Che, H. Z., Zhang, X. Y., Li, Y., Zhou, Z. J., and Qu, J. J.: Horizontal visibility trends in China 1981-2005, Geophys. Res. Lett., 34, 2007.

Chiacchio, M., Ewen, T., Wild, M., Chin, M., and Diehl, T.: Decadal variability of aerosol optical depth in Europe and its relationship to the temporal shift of the North Atlantic Oscillation in the realm of dimming and brightening, J. Geophys. Res., 116, D02108, doi:10.1029/2010JD014471, 2010.

Chiacchio, M., Ewen, T., Wild, M., Chin, M. A., and Diehl, T.: Decadal variability of aerosol optical depth in Europe and its relationship to the temporal shift of the North Atlantic Oscillation in the realm of dimming and brightening, J. Geophys. Res., 116, D02108, doi:10.1029/2010jd014471, 2011.

Colette, A., Granier, C., Hodnebrog, Ø., Jakobs, H., Maurizi, A., Nyiri, A., Bessagnet, B., D’Angiola, A., D’Isidoro, M., Gauss, M., Meleux, F., Memmesheimer, M., Mieville, A., Rouïl, L., Russo, F., Solberg, S., Stordal, F., and Tampieri, F.: Air quality trends in Europe over the past decade: a first multi-model assessment, Atmos. Chem. Phys., 11, 11657-11678, doi:10.5194/acp11-11657-2011, 2011.

Cooper, J. R., Collins, R., Massey, T. H., Venkateswaran, N., and Westaway, S.: Sulphur removal from flue gases in the utility sector: Practicalities and economics, Proc. Inst. Mech. Eng. Part A - J. Power Energy, 211, 11-26, 10.1243/0957650971536962, 1997.

Crounse, J. D., DeCarlo, P. F., Blake, D. R., Emmons, L. K., Campos, T. L., Apel, E. C., Clarke, A. D., Weinheimer, A. J., McCabe, D. C., Yokelson, R. J., Jimenez, J. L., and Wennberg, P. O.: Biomass burning and urban air pollution over the Central Mexican Plateau, Atmos. Chem. Phys., 9, 4929-4944, doi:10.5194/acp-9-4929-2009, 2009.

Cusack, M., Alastuey, A., Pérez, N., Pey, J., and Querol, X.: Trends of particulate matter $\left(\mathrm{PM}_{2.5}\right)$ and chemical composition at a regional background site in the Western Mediterranean over the last nine years (2002-2010), Atmos. Chem. Phys., 12, 8341-8357, doi:10.5194/acp-12-8341-2012, 2012.

den Outer, P. N., Slaper, H., Kaurola, J., Lindfors, A., Kazantzidis, A., Bais, A. F., Feister, U., Junk, J., Janouch, M., and Josefsson, W.: Reconstructing of erythemal ultraviolet radiation levels in Europe for the past 4 decades, J. Geophys. Res., 115, D10102, doi:10.1029/2009jd012827, 2010.

Dey, S. and Di Girolamo, L.: A decade of change in aerosol properties over the Indian subcontinent, Geophys. Res. Lett., 38, L14811, doi:10.1029/2011g1048153, 2011.

Dwyer, J. G., Norris, J. R., and Ruckstuhl, C.: Do climate models reproduce observed solar dimming and brightening over China and Japan?, J. Geophys. Res., 115, D00K08, doi:10.1029/2009jd012945, 2010.

Englert, N.: Fine particles and human health - a review of epidemiological studies, Toxicol. Lett., 149, 235-242, 2004.

Fenger, J.: Air pollution in the last 50 years From local to global, Atmos. Environ., 43, 13-22, doi:10.1016/j.atmosenv.2008.09.061, 2009.

Field, R. D., van der Werf, G. R., and Shen, S. S. P.: Human amplification of drought-induced biomass burning in Indonesia since 1960, Nature Geoscience, 2, 185-188, doi:10.1038/ngeo443, 2009.
Garcia-Herrera, R., Diaz, J., Trigo, R. M., Luterbacher, J., and Fischer, E. M.: A Review of the European Summer Heat Wave of 2003, Crit. Rev. Environ. Sci. Technol., 40, 267-306, doi:10.1080/10643380802238137, 2010.

Giglio, L., van der Werf, G. R., Randerson, J. T., Collatz, G. J., and Kasibhatla, P.: Global estimation of burned area using MODIS active fire observations, Atmos. Chem. Phys., 6, 957974, doi:10.5194/acp-6-957-2006, 2006.

Hand, J. L. and Malm, W. C.: Review of aerosol mass scattering efficiencies from ground-based measurements since 1990, J. Geophys. Res., 112, D16203, doi:10.1029/2007JD008484, 2007.

Hirdman, D., Burkhart, J. F., Sodemann, H., Eckhardt, S., Jefferson, A., Quinn, P. K., Sharma, S., Ström, J., and Stohl, A.: Longterm trends of black carbon and sulphate aerosol in the Arctic: changes in atmospheric transport and source region emissions, Atmos. Chem. Phys., 10, 9351-9368, doi:10.5194/acp-10-93512010, 2010.

Hoff, R. M. and Christopher, S. A.: Remote Sensing of Particulate Pollution from Space: Have We Reached the Promised Land?, J. Air \& Waste Manage. Assoc., 59, 645-675, 2009.

Husar, R. B., Husar, J. D., and Martin, L.: Distribution of continental surface aerosol extinction based on visual range data, Atmos. Environ., 34, 5067-5078, doi:10.1016/s1352-2310(00)00324-1, 2000.

Hyvärinen, A. P., Raatikainen, T., Brus, D., Komppula, M., Panwar, T. S., Hooda, R. K., Sharma, V. P., and Lihavainen, H.: Effect of the summer monsoon on aerosols at two measurement stations in Northern India - Part 1: PM and BC concentrations, Atmos. Chem. Phys., 11, 8271-8282, doi:10.5194/acp-11-82712011, 2011.

Itahashi, S., Uno, I., Yumimoto, K., Irie, H., Osada, K., Ogata, K., Fukushima, H., Wang, Z., and Ohara, T.: Interannual variation in the fine-mode MODIS aerosol optical depth and its relationship to the changes in sulfur dioxide emissions in China between 2000 and 2010, Atmos. Chem. Phys., 12, 2631-2640, doi:10.5194/acp-12-2631-2012, 2012.

Kaufman, Y. J., Tanre, D., and Boucher, O.: A satellite view of aerosols in the climate system, Nature, 419, 215-223, 2002.

Kukkonen, J., Olsson, T., Schultz, D. M., Baklanov, A., Klein, T., Miranda, A. I., Monteiro, A., Hirtl, M., Tarvainen, V., Boy, M., Peuch, V. H., Poupkou, A., Kioutsioukis, I., Finardi, S., Sofiev, M., Sokhi, R., Lehtinen, K. E. J., Karatzas, K., San José, R., Astitha, M., Kallos, G., Schaap, M., Reimer, E., Jakobs, H., and Eben, K.: A review of operational, regional-scale, chemical weather forecasting models in Europe, Atmos. Chem. Phys., 12, 1-87, doi:10.5194/acp-12-1-2012, 2012.

Lau, W. K. M. and Kim, K. M.: Fingerprinting the impacts of aerosols on long-term trends of the Indian summer monsoon regional rainfall, Geophys. Res. Lett., 37, L16705, doi:10.1029/2010g1043255, 2010.

Lawrence, M. G. and Lelieveld, J.: Atmospheric pollutant outflow from southern Asia: a review, Atmos. Chem. Phys., 10, 1101711096, doi:10.5194/acp-10-11017-2010, 2010.

Levy, R. C., Remer, L. A., Kleidman, R. G., Mattoo, S., Ichoku, C., Kahn, R., and Eck, T. F.: Global evaluation of the Collection 5 MODIS dark-target aerosol products over land, Atmos. Chem. Phys., 10, 10399-10420, doi:10.5194/acp-10-10399-2010, 2010.

Lu, Z., Streets, D. G., Zhang, Q., Wang, S., Carmichael, G. R., Cheng, Y. F., Wei, C., Chin, M., Diehl, T., and Tan, Q.: Sulfur 
dioxide emissions in China and sulfur trends in East Asia since 2000, Atmos. Chem. Phys., 10, 6311-6331, doi:10.5194/acpd10-8657-2010, 2010.

Lyapustin, A., Smirnov, A., Holben, B., Chin, M., Streets, D. G., Lu, Z., Kahn, R., Slutsker, I., Laszlo, I., Kondragunta, S., Tanré, D., Dubovik, O., Goloub, P., Chen, H. B., Sinyuk, A., Wang, Y., and Korkin, S.: Reduction of aerosol absorption in Beijing since 2007 from MODIS and AERONET, Geophys. Res. Lett., 38, L10803, doi:10.1029/2011g1047306, 2011.

Mahowald, N. M., Ballantine, J. A., Feddema, J., and Ramankutty, N.: Global trends in visibility: implications for dust sources, Atmos. Chem. Phys., 7, 3309-3339, doi:10.5194/acp-7-3309-2007, 2007.

Menon, S., Hansen, J., Nazarenko, L., and Luo, Y. F.: Climate effects of black carbon aerosols in China and India, Science, 297, 2250-2253, 2002.

Mitchell, R. M., Campbell, S. K., and Qin, Y.: Recent increase in aerosol loading over the Australian arid zone, Atmos. Chem. Phys., 10, 1689-1699, 2010,

http://www.atmos-chem-phys.net/10/1689/2010/.

Murphy, D. M., Chow, J. C., Leibensperger, E. M., Malm, W. C., Pitchford, M., Schichtel, B. A., Watson, J. G., and White, W. H.: Decreases in elemental carbon and fine particle mass in the United States, Atmos. Chem. Phys., 11, 4679-4686, doi:10.5194/acp-11-4679-2011, 2011.

Myhre, G.: Consistency Between Satellite-Derived and Modeled Estimates of the Direct Aerosol Effect, Science, 325, 187-190, doi:10.1126/science.1174461, 2009.

Nan, G. D.: Sulfur dioxide emissions and United States new regulation, Resour. Policy, 20, 71-75, doi:10.1016/03014207(94)90042-6, 1994.

Nicole Pauly, H.: Impaired visibility: the air pollution people see, Atmos. Environ., 43, 182-195, doi:10.1016/j.atmosenv.2008.09.067, 2009.

Pozzoli, L., Janssens-Maenhout, G., Diehl, T., Bey, I., Schultz, M. G., Feichter, J., Vignati, E., and Dentener, F.: Re-analysis of tropospheric sulfate aerosol and ozone for the period 1980-2005 using the aerosol-chemistry-climate model ECHAM5-HAMMOZ, Atmos. Chem. Phys., 11, 9563-9594, doi:10.5194/acp-11-95632011, 2011.

Price, M., Bulpitt, S., and Meyer, M. B.: A comparison of $\mathrm{PM}_{10}$ monitors at a Kerbside site in the northeast of England, Atmos. Environ., 37, 4425-4434, doi:10.1016/s1352-2310(03)00582-x, 2003.

Putaud, J. P., Raes, F., Van Dingenen, R., Bruggemann, E., Facchini, M. C., Decesari, S., Fuzzi, S., Gehrig, R., Huglin, C., Laj, P., Lorbeer, G., Maenhaut, W., Mihalopoulos, N., Mulller, K., Querol, X., Rodriguez, S., Schneider, J., Spindler, G., ten Brink, H., Torseth, K., and Wiedensohler, A.: A European aerosol phenomenology-2: chemical characteristics of particulate matter at kerbside, urban, rural and background sites in Europe, Atmos. Environ., 38, 2579-2595, doi:10.1016/j.atmosenv.2004.01.041, 2004.

Putaud, J. P., Van Dingenen, R., Alastuey, A., Bauer, H., Birmili, W., Cyryse, J., Flentje, H., Fuzzi, S., Gehrigh, R., Hansson, H. C., Harrison, R. M., Herrmann, H., Hitzenberger, R., Huglin, C., Jones, A. M., Kasper-Giebl, A., Kiss, G., Kousa, A., Kuhlbusch, T. A. J., Loschau, G., Maenhaut, W., Molnar, A., Moreno, T., Pekkanen, J., Perrino, C., Pitz, M., Puxbaum, H., Querol, X.,
Rodriguez, S., Salma, I., Schwarz, J., Smolik, J., Schneider, J., Spindler, G., ten Brink, H., Tursic, J., Viana, M., Wiedensohler, A., and Raes, F.: A European aerosol phenomenology-3: Physical and chemical characteristics of particulate matter from 60 rural, urban, and kerbside sites across Europe, Atmos. Environ., 44, 1308-1320, doi:10.1016/j.atmosenv.2009.12.011, 2010.

Querol, X., Alastuey, A., Ruiz, C. R., Artinano, B., Hansson, H. C., Harrison, R. M., Buringh, E., ten Brink, H. M., Lutz, M., Bruckmann, P., Straehl, P., and Schneider, J.: Speciation and origin of $\mathrm{PM}_{10}$ and $\mathrm{PM}_{2.5}$ in selected European cities, Atmos. Environ., 38, 6547-6555, 2004.

Ramanathan, V., Ramana, M. V., Roberts, G., Kim, D., Corrigan, C., Chung, C., and Winker, D.: Warming trends in Asia amplified by brown cloud solar absorption, Nature, 448, 575-578, 2007.

Reid, J. S., Koppmann, R., Eck, T. F., and Eleuterio, D. P.: A review of biomass burning emissions part II: intensive physical properties of biomass burning particles, Atmos. Chem. Phys., 5, 799825, doi:10.5194/acp-5-799-2005, 2005.

Rosa, I. M. D., Pereira, J. M. C., and Tarantola, S.: Atmospheric emissions from vegetation fires in Portugal (1990-2008): estimates, uncertainty analysis, and sensitivity analysis, Atmos. Chem. Phys., 11, 2625-2640, doi:10.5194/acp-11-2625-2011, 2011.

Rosenfeld, D., Dai, J., Yu, X., Yao, Z. Y., Xu, X. H., Yang, X., and $\mathrm{Du}, \mathrm{C}$. L.: Inverse relations between amounts of air pollution and orographic precipitation, Science, 315, 1396-1398, doi:10.1126/science.1137949, 2007.

Rosenfeld, D., Lohmann, U., Raga, G. B., O’Dowd, C. D., Kulmala, M., Fuzzi, S., Reissell, A., and Andreae, M. O.: Flood or Drought: How Do Aerosols Affect Precipitation?, Science, 321, 1309-1313, doi:10.1126/science.1160606, 2008.

Ruckstuhl, C., Norris, J. R., and Philipona, R.: Is there evidence for an aerosol indirect effect during the recent aerosol optical depth decline in Europe?, J. Geophys. Res., 115, D04204, doi:10.1029/2009jd012867, 2010.

Schaap, M., Apituley, A., Timmermans, R. M. A., Koelemeijer, R. B. A., and de Leeuw, G.: Exploring the relation between aerosol optical depth and $\mathrm{PM}_{2.5}$ at Cabauw, the Netherlands, Atmos. Chem. Phys., 9, 909-925, doi:10.5194/acp-9-909-2009, 2009.

Streets, D. G., Fu, J. S., Jang, C. J., Hao, J. M., He, K. B., Tang, X. Y., Zhang, Y. H., Wang, Z. F., Li, Z. P., Zhang, Q., Wang, L. T., Wang, B. Y., and Yu, C.: Air quality during the 2008 Beijing Olympic Games, Atmos. Environ., 41, 480-492, 2007.

Trigo, R. M., Pereira, J. M. C., Pereira, M. G., Mota, B., Calado, T. J., Dacamara, C. C., and Santo, F. E.: Atmospheric conditions associated with the exceptional fire season of 2003 in Portugal, Int. J. Climatol., 26, 1741-1757, doi:10.1002/joc.1333, 2006.

Tsigaridis, K., Krol, M., Dentener, F. J., Balkanski, Y., Lathière, J., Metzger, S., Hauglustaine, D. A., and Kanakidou, M.: Change in global aerosol composition since preindustrial times, Atmos. Chem. Phys., 6, 5143-5162, doi:10.5194/acp-6-5143-2006, 2006.

Tsyro, S. G.: To what extent can aerosol water explain the discrepancy between model calculated and gravimetric $\mathrm{PM}_{10}$ and $\mathrm{PM}_{2.5}$ ?, Atmos. Chem. Phys., 5, 515-532, doi:10.5194/acp-5515-2005, 2005.

van der Werf, G. R., Randerson, J. T., Giglio, L., Collatz, G. J., Kasibhatla, P. S., and Arellano Jr, A. F.: Interannual variability in global biomass burning emissions from 1997 to 2004, At- 
mos. Chem. Phys., 6, 3423-3441, doi:10.5194/acp-6-3423-2006, 2006.

Van Dingenen, R., Raes, F., Putaud, J. P., Baltensperger, U., Charron, A., Facchini, M. C., Decesari, S., Fuzzi, S., Gehrig, R., Hansson, H. C., Harrison, R. M., Huglin, C., Jones, A. M., Laj, P., Lorbeer, G., Maenhaut, W., Palmgren, F., Querol, X., Rodriguez, S., Schneider, J., ten Brink, H., Tunved, P., Torseth, K., Wehner, B., Weingartner, E., Wiedensohler, A., and Wahlin, P.: A European aerosol phenomenology-1: physical characteristics of particulate matter at kerbside, urban, rural and background sites in Europe, Atmos. Environ., 38, 2561-2577, doi:10.1016/j.atmosenv.2004.01.040, 2004.

van Oldenborgh, G. J., Yiou, P., and Vautard, R.: On the roles of circulation and aerosols in the decline of mist and dense fog in Europe over the last 30 years, Atmos. Chem. Phys., 10, 45974609, doi:10.5194/acp-10-4597-2010, 2010.

Vautard, R., Yiou, P., and van Oldenborgh, G. J.: Decline of fog, mist and haze in Europe over the past 30 years, Nature Geosci., 2, 115-119, doi:10.1038/ngeo414, 2009.

Wang, J., Li, H., and Hao, X.: Responses of snowmelt runoff to climatic change in an inland river basin, Northwestern China, over the past 50 years, Hydrol. Earth Syst. Sci., 14, 1979-1987, doi:10.5194/hess-14-1979-2010, 2010.

Wang, K., Dickinson, R. E., and Liang, S.: Clear sky visibility has decreased over land globally from 1973 to 2007, Science, 323, 1468-1470, doi:10.1126/science.1167549, 2009.

Wang, Z., and Chen, J.: A Greener Future for China's Cities, Science, 327, p. 1199, 2010.
Watson, J. G.: Visibility: science and regulation, J. Air \& Waste Manage. Assoc., 52, 628-628, 2002.

Williams, R., Suggs, J., Rodes, C., Lawless, P., Zweidinger, R., Kwok, R., Creason, J., and Sheldon, L.: Comparison of $\mathrm{PM}_{2.5}$ and $\mathrm{PM}_{10}$ monitors, J. Expo. Anal. Environ. Epidemiol., 10, 497-505, doi:10.1038/sj.jea.7500138, 2000.

Yoon, J., von Hoyningen-Huene, W., Kokhanovsky, A. A., Vountas, M., and Burrows, J. P.: Trend analysis of aerosol optical thickness and Ångström exponent derived from the global AERONET spectral observations, Atmos. Meas. Tech., 5, 12711299, doi:10.5194/amt-5-1271-2012, 2012.

Zhang, J., and Reid, J. S.: A decadal regional and global trend analysis of the aerosol optical depth using a data-assimilation grade over-water MODIS and Level 2 MISR aerosol products, Atmos. Chem. Phys., 10, 10949-10963, doi:10.5194/acp-1010949-2010, 2010.

Zhao, T. X. P., Laszlo, I., Guo, W., Heidinger, A., Cao, C., Jelenak, A., Tarpley, D., and Sullivan, J.: Study of long-term trend in aerosol optical thickness observed from operational AVHRR satellite instrument, J. Geophys. Res., 113, D07201, doi:10.1029/2007jd009061, 2008.

Zhu, L., Huang, X., Shi, H., Cai, X., and Song, Y.: Transport pathways and potential sources of $\mathrm{PM}_{10}$ in Beijing, Atmos. Environ., 45, 594-604, doi:10.1016/j.atmosenv.2010.10.040, 2011. 